THURSDAY, JULY 17, 1873

\section{THE PAY OF SCIENTIFIC MEN}

$\mathrm{T}$ HERE are a good many points of interest attaching to the Parliamentary paper referring to the pay of the officers of the British Muscum, which, thanks to Lord George Hamilton, has been issued during this week.

It shows in a striking manner what the Government thinks of Science and its votaries; nor is this all : it shows in a not less striking manncr how it behoves men of Science, if they consider that there should be a career for Science at all, to at once take some action, in order that their real claims may be conceded. Mr. Lowe, in defending not long ago the high rate of pay of Treasury clerks, who "begin" at $250 \%$. a year and rise quickly to $1,200 l$. (if they are unfortunate enough not to get a staff appointment with much higher pay, long before they would, in the ordinary course of promotion, reach the senior class), stated that what was principally wanted at the Treasury, over and above the ordinary qualities of a clerk, was a certain "freemasonry," which was best got at the public schools. For this "freemasorry" Mr. Lowe is willing to pay $150 \%$. a ycar over and above the $100 \%$. which is the usual commencing pay of a junior clerk in the other Crown offices.

Perhaps it is too much to say that this "Frecmasonry" is required in the British Museum. But there is certainly something required in the case of the scientific appointments there, of as special a character; and that is a knowledge of Science.

What then does Mr. Lowe do to secure this specialty? He gives the man of Science who enters the Museum the magnificent sum of $90 l$. per annum on entrance, with the still more magnificent--but, unfortunately, very distantprospect of attaining an income of $600 \%$. So that :-

Public School Freemasonry : Scientific Attainments : : $250 l$ : : $90 \%$.

This state of things has recently been brought home to the Trustees by petitions from all grades in the Muscum, and a sub-committee of the Trustees has reported that, "owing to the insufficiency of the salaries, the slowness of their progressive rise, and the lowness of their maximum, the trustees are losing, and will continue to lose, their best men."

As a result of this report, in which we consider that higher ground might have been taken, the Trustees have proposed a new scale to the Treasury, the only fault of which is that-with the exception of the case of principal Librarian, who is not a specialist, who has no special work to do which could not be done by the keepers acting in tum as Dean, and who already has just double the salary of the most highly-paid keeper-it is far too modest. As the Daily Nerus has well put it, a maximum of $500 l$. is "certainly not a too lavish position for a man who must be a scholar and linguist, an archrologist, natualist, or chemist, and must in most cases be alrcady in middle life."

The men upon whoše heads, hands, reputation, and work the success and fame of the Museum depend, are No. 194-VoL. viri. the keepers, whose pay, even as revised, is a mere pittance for such service as they render.

Altogether, the eventual total increas ed annual expenditure would amount to $5,700 l$. a year-the pay of onc political or legal placeman, who has properly employed his "Freemasonry."

Here is the Treasury reply :-

"Treasury Chambers, NIarch 28, 1873

"My Lords and Gentlemen,-The Lords Commissioners of Her Majesty's Treasury have had before them two letters from Mr. Winter Jones, dated the 4 th instant, submitting recommendations for the grant of increase of salary to the principal Librarian and Secretary, and to various other officers of your establishment, and they desire me to say that, after giving their most careful consideration to all the statements put before them, they regret that they would not feel warranted in acceding to any alteration in the present scale of salaries.

$$
\text { (Signed) "I have, \&c. }
$$

We trust that some determined stand will be made by the Trustees-among whom is the Right Hon. Robert Lowe-against this monstrous letter; and we trust also that some general protest will be made by men of Science and Culture generally against this latest valuation of these acquirements by the Government.

The man of Science serves his country as well as the politician, the lawyer, the soldier, or the sailor, although perhaps his claims are not stated in so blatant a manner, nor are at present so generally acknowledged, whether they will be in the future must to a large extent depend upon men of Science themselves: but whether this be conceded or not, surely in a country where the State remuneration for services performed is extraordinarily high in the upper appointments, our scientific chiefs in the public service should at all events receive the means of a decent livelihood, and such men as are employed in the British Museum, many of whom have world-wide reputations, should at least be treated as well as Government clerks.

Surely this is not to ask too much? Nay, it is already conceded by the Government in many departments where special scientific knowledge is required of no higher order than that which is so shabbily treated in the one Institution of which we have the greatest reason to be proud.

\section{THE "POLARIS" ARCTIC EXPEDITION}

$W^{\mathrm{E}}$ have just received the printed Report, presented to the President of the United States by the naval authorities, of the result of their examination of those of the crew of the Polaris, who, in October last, were severed from that ship, and drifted on an ice-floe from about $80^{\circ}$ north latitude during the whole of the winter until, 600 miles south from their startingpoint, they were picked up on April 30 , of this year, by the Tigress off the coast of Labrador. The Report fur nishes material for one more of those thrilling narratives of Arctic adventure, which will be the delight of the boyhood of all generations, and which, commencing in the Ioth century with that of Bjorne the Norseman, have been accumulating in increasing proportion, and will never fail to be added to until not a shred of mystery re. mains to unravel within the Arctic circle. The advocates of Arctic exploration by way of Smith's Sound, needed 